\title{
Selective D-1 dopamine receptor agonist effects in hyperkinetic extrapyramidal disorders
}

\author{
A BRAUN, M M MOURADIAN, E MOHR, G FABBRINI, T N CHASE \\ From the Experimental Therapeutics Branch, National Institute of Neurological and Communicative Disorders \\ and Stroke National Institutes of Health, Department of Health and Human Services, Bethesda, USA
}

SUMMARY The motor and cognitive effects of a selective D-1 dopamine receptor agonist, SKF 39393, were assessed in patients with Huntington's disease, Gilles de la Tourette's syndrome, tardive dyskinesia, and torsion dystonia, using a double-blind placebo-controlled design. Over daily doses ranging from 3.2 to $32 \mathrm{mg} / \mathrm{kg}$ and treatment intervals extending from one to seven weeks, no consistent changes could be discerned. The contribution of D-1 receptor mediated mechanisms to the pathophysiology of hyperkinetic extrapyramidal disorders remains uncertain.

Dopaminergic mechanisms appear to play a central role in the pathophysiology of hyperkinetic extrapyramidal disorders. Within the past decade, two general subclasses of dopamine receptors have been identified. The D-1 receptor mediates the stimulatory effects of dopamine on adenylate cyclase, while the D2 receptor is either unassociated with or negatively linked to this enzyme. 'Introduction of agents selective for these receptor subtypes has facilitated studies of the functional roles of D-1 and D-2 and D-2 receptor mediated mechanisms, ${ }^{23}$ and has yielded information that may assist in the development of improved pharmacotherapy of extrapyramidal disease.

The D-2 dopamine receptor has previously been considered most closely related to extrapyramidal motor function. ${ }^{4}$ Nevertheless, recent preclinical observations suggest that D-1 receptors may also participate in the generation of involuntary and cognitive deficits that attend certain hyperkinetic disorders. ${ }^{5-9}$ Clinical experience also supports the notion that $\mathrm{D}-1$ receptor mediated mechanisms contribute to the production of choreiform movements. Treatment of Parkinson's disease with non-selective D-1/D-2 dopaminomimetics such as levodopa results in doselimiting facial, appendicular and axial dyskinesias. When treatment is initiated with the relatively selective D-2 agonist bromocriptine, the appearance of these movements may be delayed. ${ }^{10}$ Studies in the experimental animal also implicate $D$-1 receptor mechanisms in the behavioural alterations that occur

Address for reprint requests: Thomas N Chase, MD, Building 10, Room 5C103, Experimental Therapeutics Branch, NINCDS, 9000 Rockville Pike, Bethesda, MD 20892, USA.

Received 6 September 1988 and in revised form 30 December 1988. Accepted 10 January 1989 in Huntington's disease and Gilles de la Tourette's syndrome. For example, D-1 receptor stimulation appears to modify attentional mechanisms in rats, alter the animals' responses to novel and noxious stimuli, and affect their ability to switch from one behavioural set to another."

In an attempt to evaluate the contribution of D-1 dopamine receptor mediated mechanisms to the motor and cognitive changes associated with hyperkinetic extrapyramidal disease, SKF 38393 , a selective D-1 receptor agonist ${ }^{2}$ was administered under doubleblind placebo-controlled design conditions to patients with Huntington's disease, Gilles de la Tourette's syndrome, tardive dyskinesia and torsion dystonia.

\section{Methods}

Five patients with Huntington's disease ( 3 men, 2 women; ages 24 to 77 years), two with Gilles de la Tourette's syndrome ( 2 males, ages 25 and 35 ), two with tardive dyskinesia (one male and one female, ages 62 and 65), and one with idiopathic torsion dystonia (male, age 27), consented to participate in this study after full disclosure of its purposes, risks and potential benefits. All centrally active drugs had been withdrawn at least two weeks prior to hospital admission for this therapeutic trial.

In the patients with Huntington's disease, choreiform movements had been present for 2 to 20 years and ranged from mild to moderately severe in the untreated state. Diagnosis was based on clinical features, family history suggestive of an autosomal dominant pattern of inheritance, and evidence of caudate atrophy on CT scan. Psychometric evaluation classified all these patients in the impaired range: mean full scale IQ 74, range 59-87; verbal IQ 79, range 67-95, performance IQ 72, range 58-80; memory quotient 73 , range 61-88; Mattis dementia rating scale 113, range 93-126.

Both patients with Gilles de la Tourette's syndrome (DSM IIIR criteria) had mild to moderate vocal and motor tics 
which had presented before age 16 years. Patient 6 , who had experienced tics for 31 years, also evidenced moderately severe obsessive-compulsive symptomatology. Patient 7 , who had had tics for 10 years, also gave a history of attentional deficit disorder and continued to manifest these symptoms during the study. His neuropsychological testing revealed definite cognitive dysfunction (table 4).

Patients with tardive dyskinesia were not psychotic; both had been treated with neuroleptics for symptoms of unipolar depression (13 months in patient 8 and 4 years in patient 9 ). Patient 8 manifested moderate to severe choreatic and dystonic movements of the trunk and extremities as well as akathisia. Patient 9 had moderate to severe linguo-facialbuccal and upper extremity chorea.

One patient with idiopathic torsion-dystonia had severe facial, axial and appendicular dystonic movements as well as incapacitating dystonia of the pharyngeal musculature. These movements had presented and progressed since 20 years of age and had not significantly improved following unilateral thalamotomy 5 years prior to this study.

SKF 38393 (Research Biochemicals, Inc., Wayland, MA) was administered orally in a double-blind, placebo-controlled, cross-over design. Dosage was gradually increased over a period of 10 to 14 days to a maximum of 11 to $32 \mathrm{mg}$ / kg given in three divided doses. SKF 38393 was then withdrawn except in the two patients with tardive dyskinesia, where the period of active drug treatment was extended to 33 and 50 days.

In Huntington's disease, tardive dyskinesia and torsion dystonia, abnormal involuntary movements were evaluated by two independent observers following administration of placebo or drug using a modification of the Abnormal Involuntary Movement Scale (AIMS). Movement severity in selected body parts was rated on a scale of 0 (absent) to 4 (severe). In patients with tardive dyskinesia, the acute response to SKF 38393 was evaluated over the first 2 weeks of drug treatment. Patients with Gilles de la Tourette's syndrome, while on placebo and again on maximum doses of SKF 38393, were videotaped during the performance of a standard motor sequence (seated at rest, seated with arms held outstretched and while performing repeated finger to nose movements, and walking) which took approximately 5 minutes and was repeated 7 to 10 times daily. Videotapes were subsequently randomised and evaluated by two neurologists unaware of the patients' treatment status. Tics which were characteristic for either patient were counted in each timed sequence and a mean frequency (tics/min) was calculated for each day.

Treatment related changes in cognitive function were evaluated in patients with Huntington's disease using a comprehensive neuropsychological test battery (table 2). A modification of this test battery was used to evaluate functions purportedly impaired in Gilles de la Tourette's syndrome (table 4). The entire battery, which took approximately 60 minutes to perform, was begun one hour after the administration of the third daily dose of placebo or of the maximum dose of SKF $38393(12 \pm 1.0 \mathrm{mg} / \mathrm{kg}$ in Huntington's disease patients; 9.1 and $9.8 \mathrm{mg} / \mathrm{kg}$ in patients with Gilles de la Tourette's syndrome.)

Data were tested for significance using one way factorial and repeated measures analysis of variance and least significant difference multiple range tests.

\section{Results}

In Huntington's disease patients, there was no consis-

Table 1 Effect of placebo and various SKF 38393 doses on choreatic movements in Huntington's disease

\begin{tabular}{|c|c|c|c|c|c|}
\hline Patient & Placebo & $2 \cdot 6-3 \cdot 8$ & $6 \cdot 0-7 \cdot 7$ & $10-15$ & 우 \\
\hline $\begin{array}{l}1 \\
2 \\
3 \\
4 \\
5 \\
\text { Mean (SEM) }\end{array}$ & $\begin{array}{l}11 \\
19 \\
19 \\
24 \\
18 \\
18(2 \cdot 0)\end{array}$ & $\begin{array}{l}12 \\
15 \\
20 \\
28 \\
15 \\
18(3 \cdot 6)\end{array}$ & $\begin{array}{l}12 \\
18 \\
18 \\
23 \\
16 \\
18(1 \cdot 8)\end{array}$ & $\begin{array}{l}11 \\
18 \\
16 \\
15 \\
19 \\
18(2 \cdot 3)\end{array}$ & 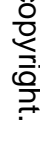 \\
\hline
\end{tabular}

Values are the mean of 2 ratings by 2 independent observers evaluated 90 minutes after the third daily dose of placebo or SKF 38393 at three different daily dose levels $(3.2 \pm 0.3 \mathrm{mg} / \mathrm{kg}$, range 2.6 to $3.8 \mathrm{mg} / \mathrm{kg} ; 6.8 \pm 0.4 \mathrm{mg} / \mathrm{kg}$, range 6.0 to $7.7 \mathrm{mg} / \mathrm{kg}$; and $12.4 \pm 1.0 \mathrm{mg} / \mathrm{kg}$, range 10.1 to $15.1 \mathrm{mg} / \mathrm{kg}$ ). Choreatic movements were rated on a scale of 0 (absent) to 4 (severe), in each of 10 categories and then summed, the maximum possible score being 40 .

Table 2 Effect of SKF 38393 on cognitive function in Huntington's disease

\begin{tabular}{|c|c|c|c|c|}
\hline & Maximum & $\begin{array}{l}\text { Baseline } \\
\text { Mean (SEM) }\end{array}$ & $\begin{array}{l}\text { Placebo } \\
\text { Mean (SEM) }\end{array}$ & $\begin{array}{l}\text { SKF } 38393 \\
\text { Mean }(S E M)\end{array}$ \\
\hline $\begin{array}{l}\text { Attention: } \\
\text { Digit Span Forward } \\
\text { Digit Span Backward } \\
\text { Simple Reaction Time } \\
\text { Go/No Go Reaction Time }\end{array}$ & $\begin{array}{l}- \\
-\end{array}$ & $\begin{array}{r}4 \cdot 8(0 \cdot 5) \\
2 \cdot 5(0 \cdot 3) \\
629(54 \cdot 2) \\
1608(684 \cdot 8)\end{array}$ & $\begin{array}{r}4 \cdot 8(0 \cdot 6) \\
3 \cdot 0(0 \cdot 4) \\
434(24 \cdot 3) \\
1987(847 \cdot 1)\end{array}$ & $\begin{aligned} 5 \cdot 0(0 \cdot 7) \\
\cdot 0(0.4) \\
1 \overline{555}(522)\end{aligned}$ \\
\hline $\begin{array}{l}\text { Verbal Function: } \\
\text { Paired Associate Learning (Immediate Recall) } \\
\text { Paired Associate Learning ( } 30 \text { Minute Delayed Recall) } \\
\text { Verbal Fluency }\end{array}$ & $\begin{array}{r}7 \\
7 \\
-\end{array}$ & $\begin{array}{l}2 \cdot 2(0 \cdot 4) \\
2 \cdot 2(0 \cdot 6) \\
12(2 \cdot 5)\end{array}$ & $\begin{array}{l}2 \cdot 0(0 \cdot 4) \\
2 \cdot 5(0 \cdot 6) \\
10(2 \cdot 0)\end{array}$ & $\begin{array}{l}2 \cdot 4(0 \cdot 3) \\
2 \cdot 6(0 \cdot 3) \\
13(1 \cdot 3)\end{array}$ \\
\hline $\begin{array}{l}\text { Visuospatial Function: } \\
\text { Embedded Figures } \\
\text { Street Map Away } \\
\text { Street Map Towards } \\
\text { Non-Verbal Fluency }\end{array}$ & $\begin{array}{l}10 \\
16 \\
16 \\
40\end{array}$ & $\begin{array}{c}4 \cdot 8(1 \cdot 7) \\
14(2 \cdot 2) \\
13(1 \cdot 7) \\
14(6 \cdot 6)\end{array}$ & $\begin{array}{l}4 \cdot 3(2 \cdot 0) \\
14(1 \cdot 3) \\
14(1 \cdot 5) \\
15(6 \cdot 7)\end{array}$ & $\begin{array}{l}5 \cdot 5(0 \cdot 9) \\
12(2 \cdot 1) \\
13(0 \cdot 2) \\
17(6 \cdot 6)\end{array}$ \\
\hline
\end{tabular}

Attentional parameters were tested with digit span, ${ }^{21}$ and with reaction time, consisting of simple and complex response paradigms (go/nogo response) ${ }^{22}$; verbal cognitive tests assessed both episodic and semantic aspects of memory, through paired associate learning, ${ }^{23}$ as well as immediate and delayed recall and verbal fluency; ${ }^{24}$ visuospatial tasks included embedded figures ${ }^{25}$ street $^{\text {map }}{ }^{26}$ and non-verbal fluency ${ }^{27}$ tests. $^{2}$ 
Table 3 Effect of SKF 38393 on tic frequency in Gilles de la Tourette's syndrome

\begin{tabular}{llll}
\hline Patient & Region & $\begin{array}{l}\text { Placebo } \\
\text { Mean }(S E M)\end{array}$ & $\begin{array}{l}\text { SKF 38393 } \\
\text { Mean }(S E M)\end{array}$ \\
\hline 6 & Eyes: & $4 \cdot 2(1 \cdot 3)$ & $3 \cdot 3(1 \cdot 4)$ \\
& Mouth: & $6 \cdot 1(1 \cdot 1)$ & $4 \cdot 7(1 \cdot 8)$ \\
7 & Neck: & $1 \cdot 1(0 \cdot 3)$ & $2 \cdot 3(0 \cdot 4)$ \\
& Neck: & $4 \cdot 5(1 \cdot 1)$ & $2 \cdot 3(0 \cdot 7)$ \\
& Hand/Wrist: & $6 \cdot 2(3 \cdot 0)$ & $2 \cdot 6(1 \cdot 2)$ \\
& Fingers: & $37(5)$ & $30(6)$ \\
\hline
\end{tabular}

Mean (SEM) tics per minute were counted by two independent observers unaware of the patients' treatment status. Patients were videotaped during placebo administration and at the maximum SKF 38393 dose $(23 \mathrm{mg} / \mathrm{kg} /$ day for patient 6 and $27 \mathrm{mg} / \mathrm{kg} /$ day for patient 7) while performing a standard motor sequence which took approximately 5 minutes and was repeated 7 to 10 times per day.

tent alteration in abnormal voluntary movements at any of the SKF 38393 doses administered (table 1). In addition, neuropsychological assessments revealed no systematic change in cognition as a function of SKF 38393 treatment (table 2).

Patients with Gilles de la Tourette's syndrome also had no statistically significant improvement in motor function at any dose of SKF 38393, although there appeared to be a general trend towards a reduction in tic frequency (table 3). Multiple measures of attention, verbal and visuospatial cognition, and memory also failed to change with SKF 38393 treatment (table 4). Drug therapy did not have any discernable effect on the obsessive compulsive symptomatology evidenced by patient 6 (table 4 ).

Tardive dyskinesia patients had no consistent change in the severity of their involuntary movements during the administration of SKF 38393 (table 5). However, choreiform movements in patient 8 initially tended to increase, then subsided to baseline levels over the next two weeks, only to worsen abruptly when the drug was discontinued. In this individual, mean AIMS scores appeared lower during stable dose

Table 4 Effect of SKF 38393 on neuropsychological function in Gilles de la Tourette's syndrome

\begin{tabular}{lccc}
\hline & Baseline & Placebo & SKF 38393 \\
\hline Digit Span Forward & $7 / 7$ & $8 / 6$ & $8 / 5$ \\
Digit Span Backward & $7 / 5$ & $8 / 5$ & $8 / 5$ \\
Letter Attention Task & $0 / 1$ & $0 / 0$ & $0 / 0$ \\
Verbal Fluency & $32 / 32$ & $41 / 21$ & $51 / 28$ \\
Street Map Away & $0 / 3$ & $0 / 6$ & $0 / 7$ \\
Street Map Towards & $0 / 7$ & $0 / 8$ & $0 / 7$ \\
Leyton Yes Responses & $36 / 23$ & $36 / 18$ & $36 / 19$ \\
Leyton Resistance Score & $58 / 8$ & $47 / 14$ & $56 / 13$ \\
Leyton Interference Score & $40 / 45$ & $35 / 42$ & $39 / 35$ \\
\hline
\end{tabular}

Scores are for two patients with Gilles de la Tourette's syndrome (patient 6 and patient 7). Neuropsychological tests, in addition to those administered to patients with Huntington's disease (table 2), included the Letter Attention Task Omissions ${ }^{28}$ (Adapted) and the Leyton obsessional inventory. ${ }^{29}$
Table 5 Effect of SKF 38393 on involuntary movements in tardive dyskinesia and torsion dystonia

\begin{tabular}{llll}
\hline Patient & Diagnosis & $\begin{array}{l}\text { Placebo } \\
\text { Mean (SEM) }\end{array}$ & $\begin{array}{l}\text { SKF 38393 } \\
\text { Mean (SEM) }\end{array}$ \\
\hline 8 & Tardive Dyskinesia & $12(2 \cdot 5)$ & $17(1 \cdot 7)$ \\
9 & Tardive Dyskinesia & $8 \cdot 9(0 \cdot 7)$ & $8 \cdot 3(0 \cdot 5)$ \\
10 & Torsion Dystonia & $27(1 \cdot 0)$ & $29(0 \cdot 5)$ \\
\hline
\end{tabular}

Mean (SEM) AIMS scores derive from 2 blinded ratings performed after the 2nd (patients $8 \& 9$ ) or 3rd (patient 10) daily dose of drug or placebo. Choreatic movements and dystonic postures were scored on a scale of 0 (absent) to 4 (severe) in either 6 body parts (tardive dyskinesia) or 10 body parts (torsion dystonia) and these scores were then summed. SKF 38393 daily dosages were $9.5 \mathrm{mg} / \mathrm{kg} / \mathrm{day}$ for patient $8,11 \mathrm{mg} / \mathrm{kg}$ for patient 9 , and $32 \mathrm{mg} / \mathrm{kg}$ for patient 10 .

treatment (11, SEM $0 \cdot 2$; daily dose $9 \cdot 5 \mathrm{mg} / \mathrm{kg})$ than during either the initial placebo $(12$, SEM $2 \cdot 5)$ or second placebo phases $(18$, SEM $1 \cdot 3)$.

The patient with idiopathic torsion dystonia showed no apparent effect on AIMS scores at either of two doses of SKF 38393 (table 5).

There were no clinically significant adverse effects associated with SKF 38393 administration in any of the patients.

\section{Discussion}

The present results indicated that subacute administration of the selective D-1 dopamine receptor agonist, SKF 38393, over a wide range of doses had no clinically significant effect on motor function in two patients with tardive dyskinesia and in one patient with idiopathic torsion dystonia, or on either motor or cognitive function in five patients with Huntington's disease and two with Gilles de la Tourette's syndrome. It is unlikely that this lack of efficacy can be attributed to a failure of the drug to cross the blood brain barrier in pharmacologically significant amounts. Unmetabolised SKF 38393 has been demonstrated in human cerebrospinal fluid following the oral administration of doses comparable to the maximum levels used in this study. ${ }^{12}$ Moreover, doses of SKF 38393 given our patients, calculated on a $\mathrm{mg} / \mathrm{kg}$ body weight basis, approximated those which reproducibly modify motor activity in rats, ${ }^{13}$ and which produce CSF drug levels similar to those found in rat brain at the time of maximum behavioural response. ${ }^{12}$ Further, a stimulatory effect of SKF 38393, in the dose range used in this study, on prolactin secretion has been observed in humans. ${ }^{14}$ Because the D-1 agonist has no direct effect on prolactin secreting cells outside the blood brain barrier, the hormone release appears to be centrally mediated.

The negative response to SKF 38393 reported here may reflect a very limited role for D-1 receptor mediated mechanisms in hyperkinetic extrapyramidal 
motor disease. Conceivably, the pathophysiology and pharmacotherapy of these disorders may relate largely, if not exclusively, to the D-2 subclass of dopamine receptors.

Considerable preclinical evidence, nevertheless, suggests that D- 1 receptor mediated mechanisms may participate in the regulation of motor function. In rodents, concurrent stimulation of both D-1 and D-2 receptors appears necessary for the full expression of the motor and electrophysiological effects of dopamine agonists, and the D-1 receptor appears to regulate the level of response to $D-2$ receptor stimulation. ${ }^{5}$ D-1 receptor stimulation is a requirement for the induction of stereotypy, a behaviour which serves as an animal model for abnormal involuntary movements in humans. ${ }^{67}$ Chronic D-1 receptor stimulation appears to be necessary for the appearance of agonist-induced behavioural supersensitivity, a model for the chronic motor and behavioural effects of long-term dopamine agonist administration in Parkinson's disease. ${ }^{8}$ In monkeys chronically exposed to neuroleptics, selective D-1 receptor blockade produces acute dystonic reactions and oral dyskinesias, which closely resemble those seen in patients with extrapyramidal disorders.'

The inability of SKF 38393 to modify motor function in the extrapyramidal disorders studied here may reflect the fact that the drug is a partial D-1 receptor agonist. ${ }^{15}$ Conceivably, SKF 38393 may produce clinically significant effects only at doses above or below those used in the present study. Nevertheless, at least in the case of Huntington's disease, this seems unlikely since motor function was formally assessed over a broad dose range without apparent effect. Alternatively, despite its high selectively in vitro and its behavioural potency in laboratory animals, SKF 38393 may not have identical pharmacologic properties in man. If this is true, acute administration of this agent may not actually reflect the effect of $D-1$ receptor stimulation in hyperkinetic extrapyramidal disease.

Other explanations are also possible. Pathological changes in Huntington's disease involve degeneration of medium spiny neurons projecting from the striatum to primary outflow regions such as globus pallidus and substantia nigra reticulata. ${ }^{16}$ The highest cerebral concentrations of D-1 receptors are found in these regions, located presynaptically on terminals of the medium spiny afferents. ${ }^{17}$ The number of these receptors may thus be substantially reduced in Huntington's disease, and D-1 receptors could therefore be involved in the pathophysiology of this disorder by virtue of their absence. Consequently, SKF 38393 would have no effect on motor or cognitive signs. Such pathological changes appear to be unique to Huntington's disease, however, and would not readily explain the failure of SKF 38393 to affect Gilles de la Tourette's syndrome, tardive dyskinesia or torsion dystonia.

On the other hand, D-1 receptors might in fact play a role in the pathophysiology of all these disorders, but the failure of SKF 38393 to modify motor or cognitive function could be due to a ceiling effect: elevated release of endogeneous dopamine or an increase in post-synaptic receptor sensitivity in these disorders may result in maximal D-1 receptor tone which cannot be further augmented by selective agonist administration. The participation of the D1 receptor could be effectively demonstrated, in such circumstances, only by the use of selective antagonists. Results of a previous study ${ }^{18}$ suggest that mixed D-1/D-2 receptor antagonists and relatively selective $\mathrm{D}-2$ receptor antagonists may have different effects on choreiform movements in certain extrapyramidal disorders.

Finally, D-1 dopamine receptors might contribute to the pathophysiology of these disorders by virtue of their interaction with D-2 receptors, a possibility which is not directly addressed in the present study. Preclinical investigations have documented a complex functional interaction between D-1 and D-2 receptors and suggested that the D-1 receptor may exert its most profound effects only when the D-2 receptor is concurrently stimulated. ${ }^{11}{ }^{19} 20$ Indeed, some studies suge gest that such an interaction may be essential. ${ }^{5-1}$ Clinical observations support this possibility; SK 38393 administered alone has no apparent effect on $\overrightarrow{0}$ motor function in Parkinson's disease, but ma modify dyskinesias induced by levodopa. ${ }^{12}$ If $\dot{a}$ functional interaction between receptor subtypes plays a role in the pathogenesis of motor or cognitive phenomena associated with hyperkinetic extrapyramidal disease, it will necessarily be documented only by further studies utilising combinations of selective D-1 and D-2 receptor agonists or antagonists.

In summary, our results suggest that the subacute administration of the D-1 receptor agonist SKF 38393 has no clinically significant effect on motor or cognitive function in patients with various hyperkinetic extrapyramidal disorders. While these negative results may be due to methodological limitations, they might also suggest the D-1 receptor mediated mechanisms do not contribute significantly to the pathophysiology of these diseases. On the other hand, the D-1 receptor may in fact play a substantial role in the pathogenesis of hyperkinetic extrapyramidal disorders which cannot be adequately characterised by the administration of SKF 38393.

\section{References}

1 Kebabian JW, Calne DB. Multiple receptors for dopamine. Nature 1979;277:93-6. .

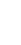


2 Setler PE, Sarau HM, Zirkle CL, Saunders HL. The central effects of novel dopamine agonist. Eur J Pharmacol 1978;50:419-30.

3 Titus RD, Kornfeld EC, Jones ND, et al. Resolution and Absolute Configuration of an Ergoline-Related Dopamine Agonist, trans-4,4a,5,6,7,8,8a,9-octahydro-5-propyl-1H (or $2 \mathrm{H}$ )-pyrazolo[3,4-g]quinoline. J Med Chem 1982;26:1112-6.

4 Creese I, Sibley DR, Hamblin MW, Leff SE. The classification of dopamine receptors: relationship to radioligand binding. Ann Rev Neurosci 1983;6:43-71.

5 Walters JR, Bergstrom DA, Carlson JH, Chase TN, Braun AR. D-1 dopamine receptor activation required for postsynaptic expression of D-2 agonist effects. Science 1987;236:719-22.

6 Braun AR, Chase TN. Obligatory D-1/D-2 receptor interaction in the generation of dopamine agonist related behaviours. Eur $J$ Pharmacol 1986;13:301-6.

7 Arnt J, Hyttel J, Perregaard J. Dopamine D-1 receptor agonists combined with the selective D-2 agonist quinpirole facilitate the expression of oral stereotyped behaviour in rats. Eur $J$ Pharmacol 1987;133:137-45.

8 Braun AR, Chase TN. Behavioral Effects of Chronic Exposure to Selective D-1 and D-2 Dopamine Receptor Agonists. Eur J Pharmacol 1988;147:441-51.

9 Kistrup K, Gerlach J. Selective $D_{1}$ and $D_{2}$ receptor manipulation in Cebus monkeys: relevance for dystonia and dyskinesia in humans. Pharmacol Toxicol 1987;61:157-61.

10 Lees AJ, Stern GM. Sustained bromocriptine therapy in previously untreated patients with Parkinson's disease. $J$ Neurol Neurosurg Psychiatry 1981;44:1020-3.

11 Braun AR, Barone P, Chase TN. Interaction of D-1 and D-2 dopamine receptors in the expression of dopamine agonist induced behaviours. Adv Exp Med Biol 1986;204:151-66.

12 Braun A, Fabbrini G, Mouradian MM, Serrati C, Barone P, Chase TN. Selective D-1 Dopamine Receptor Agonist Treatment of Parkinson's Disease. J Neural Transm 1987;68:41-50.

13 Molloy AG, Waddington JL. Dopaminergic behavior stereospecifically promoted by the $D_{1}$ agonist R-SKF-38393 and selectively blocked by the $D_{1}$ antagonist SCH 23390. Psychopharmacology 1984;82:409-10.

14 Fabbrini G, Braun A, Mouradian MM, Tamminga CA, Chase TN. Dopamine D-1 receptor agonist stimulation of prolactin secretion in man. J Neural Transm 1988;71:155-63.

15 Leff SE, Hamblin MW, Creese I. Interaction of dopamine agonists with brain D-1 receptors labelled by $3 \mathrm{H}$-antagonists. Evidence for the presence of high and low affinity agonist binding states. Mol Pharmacol 1985;27:171-83.

16 Martin JB, Gusella JF. Huntington's disease. Pathogenesis and management. $N$ Engl J Med 1986;315:1267-76.

17 Barone P, Tucci I, Parashos S, Chase TN. D-1 dopamine receptor changes after striatal quinolinic acid lesion. Eur J Pharmacol 1987;138:141-5.

18 Agnoli A, Ruggieri S, DelRoscio S, Baldassarre M, Bocola V, Denaro A. Abnormal Involuntary movements: A Study of dopaminergic receptor interaction. Adv Neurol 1983;37: 305-12.

19 Gershanik O, Heikkila RE, Duvoisin RC. Behavioural correlates of dopamine receptor activation. Neurology 1983;33:1489-92.

20 Mailman RB, Schultz DW, Lewis MH, Staples L, Rollema J, Dehaven DL. SCH 23390: A selective $D_{1}$ dopamine antagonist with potent $\mathrm{D}_{2}$ behavioral actions. Eur $J$ Pharmacol 1984;101: 159-60.

21 Wechsler D. Wechsler Adult Intelligence Scale-Revised. New York: The Psychological Corporation, 1981.

22 Luria AR. The Working Brain, An Introduction to Neuropsychology. 1966:200-1.

23 Wechsler D, Stone CP. Wechsler Memory Scale. New York: The Psychological Corporation, 1945.

24 Benton AL, des Hamsher K. Multilingual Aphasia Examination. Iowa City: University of Iowa Press, 1976.

25 Kapur N, Butters N. Visuoperceptive deficits in long term alcoholics and alcoholics with Korsakoff's psychosis. J Stud Alcohol 1977;38:2025-35.

26 Money JA. Standardized Road Map of Direction Sense. San Rafael, California: Academic Therapy Publications, 1976.

27 Jones-Gotman M, Milner B. Design fluency: The invention of nonsense drawings after focal cortical lesions. Neuropsychologia 1977;15:653-74.

28 Lezar MD. Neuropsychological Assessment, Second Ed. New York: Oxford Press, 1983.

29 Cooper J. The Leyton Obsessional Inventory. Psychol Med 1970;1: 48-64. 